\title{
Gall-forming protistan parasites infect southern bull kelp across the Southern Ocean, with prevalence increasing to the south
}

\author{
Callum Blake ${ }^{1}$, Martin Thiel ${ }^{2,3,4}$, Boris A. López ${ }^{2,5}$, Ceridwen I. Fraser $^{1, *}$ \\ ${ }^{1}$ Fenner School of Environment and Society, Australian National University, Building 141 Linnaeus Way, Acton, \\ ACT 2601, Australia \\ ${ }^{2}$ Facultad de Ciencias del Mar, Universidad Católica del Norte, Larrondo 1281, Coquimbo, Chile \\ ${ }^{3}$ Millennium Nucleus Ecology and Sustainable Management of Oceanic Island (ESMOI), Coquimbo, Chile \\ ${ }^{4}$ Centro de Estudios Avanzados en Zonas Áridas, CEAZA, Coquimbo, Chile \\ ${ }^{5}$ Departamento de Acuicultura y Recursos Agroalimentarios, Universidad de Los Lagos, Av. Fuchslocher 1305, Osorno, Chile
}

\begin{abstract}
Protistan pathogens can have devastating effects on marine plants, yet the processes that affect their distributions and infection intensities are poorly understood. Species within the brown algal genus Durvillaea are major ecosystem engineers throughout the sub-Antarctic and cold-temperate Southern Hemisphere, and a newly described genus of protistan parasite, Maullinia, was recently found infecting $D$. antarctica in Chile. We set out to address 3 key questions. (1) Is there evidence for trans-oceanic dispersal of Maullinia? (2) Does Maullinia infect other Durvillaea species? (3) Does infection prevalence vary throughout the hosts' ranges? We sampled Maullinia on Durvillaea populations along coasts in Chile (D. antarctica, from $32^{\circ}$ to $42^{\circ} \mathrm{S}$ : 8 sites), Australia (D. potatorum and D. amatheiae, from $36^{\circ}$ to $38^{\circ} \mathrm{S}$ : 5 sites) and sub-Antarctic Marion Island ( $\left.46^{\circ} 53^{\prime} 47^{\prime \prime} \mathrm{S}, 37^{\circ} 43^{\prime} 32^{\prime \prime} \mathrm{E}\right)$. We used a genetic marker (18S rRNA) to verify the presence of Maullinia on Durvillaea at all sites and visual surveys of Maullinia galls to assess infection prevalence in Chile and Australia. We confirm that Maullinia infects Australian Durvillaea species, but our results indicate that each host species is parasitised by a different Maullinia lineage. Maullinia infection prevalence increased with latitude. Long- and short-distance dispersal events are inferred to have occurred based on genetic patterns. We conclude that Maullinia protists are broadly distributed and affect multiple host species, including at least 3 Durvillaea species (2 in Australia, and 1 in both Chile and Marion Island), and that environmental factors influence host susceptibility to infection.
\end{abstract}

KEY WORDS: Pathogen - Macroalgae $\cdot$ Host-specificity $\cdot$ Intertidal $\cdot$ Dispersal $\cdot$ Durvillaea Maullinia

\section{INTRODUCTION}

The infection intensities and geographic ranges of many parasitic organisms are expected to increase under forecast scenarios of environmental change (Eggert et al. 2010, Gleason et al. 2013). These increases may prove devastating where infections affect keystone species at low trophic levels, even

\footnotetext{
*Corresponding author: ceridwen.fraser@gmail.com
}

potentially leading to ecosystem collapse (see Mouritsen et al. 2005, Collinge et al. 2008). As such, understanding the factors shaping parasite biogeography and patterns of infection is an important part of predicting how ecosystems will respond to global environmental change.

Large algae (e.g. kelps) are critical components of many shallow marine ecosystems as both food and

() The authors 2017. Open Access under Creative Commons by Attribution Licence. Use, distribution and reproduction are unrestricted. Authors and original publication must be credited. 
habitat for diverse organisms (Jones et al. 1997). The susceptibility of marine algae to pathogen infection can be influenced by factors including population density, tissue damage and life stage (Andrews 1976). Analyses of kelp pathosystems have also revealed evidence for a molecular basis to host resistance, whereby some species or genetic lineages of marine algae are more prone to infection than others (Carius et al. 2001, Gachon et al. 2009, 2010). Marine pathogen and parasite infections may increase along environmental gradients (e.g. depth, longitude and latitude), and their distributions and intensities can indicate dispersal routes and barriers, and biogeographical regions (Rohde 2002).

Durvillaea is a brown algal genus comprising large, keystone species inhabiting rocky intertidal and shallow subtidal shores in the Southern Hemisphere. In Australia, 2 Durvillaea species occur: D. amatheiae is found along the south-eastern coasts of New South Wales, Victoria and Tasmania, and D. potatorum along the coasts of eastern South Australia, western Victoria and Tasmania (Fraser et al. 2009, Weber et al. 2017). D. antarctica is not found in Australia but has a broad, circumpolar distribution that includes the sub-Antarctic islands, New Zealand and much of the coast of Chile (Fraser et al. 2010). The species is highly buoyant and dispersive, and has previously been inferred to have transported an endophytic algal parasite, Herpodiscus durvillaeae, across the Pacific Ocean (Fraser \& Waters 2013).

Maullinia is a recently identified genus of phytomyxean parasite that can infect several brown algal genera including Macrocystis, Ectocarpus and Acinetospora (Maier et al. 2000, Goecke et al. 2012). The microscopic organisms produce motile zoospores which disperse and infect new hosts, causing galllike hypertrophies of host tissue (Neuhauser et al. 2011). The production of resting spores may enable the parasite to disperse long distances and survive adverse conditions (Neuhauser et al. 2011). While some research has described phytomyxids, including Maullinia, as parasites that infect hosts without directly leading to mortality (Neuhauser et al. 2014), on flexible species such as D. antarctica the formation of galls has been suggested to reduce the host's ability to survive in high-energy wave environments (Eggert et al. 2010). In laboratory cultures, Maullinia ectocarpii was also found to heavily infect the gametophytes of algal species such as Macrocystis pyrifera (Maier et al. 2000), which could reduce the reproductive potential of its host. The host range, life cycle and infection pathway of $M$. ectocarpii are relatively well characterised, but the factors shaping its virulence in natural populations are not. The only Maullinia recorded on Durvillaea appears likely to be a newly recognised species ('Maullinia sp.' in Goecke et al. 2012; now M. braseltonii: Murúa et al. 2017). Although Australian Durvillaea populations have not yet been confirmed to host Maullinia, galls resembling those of the parasite were observed at Sorrento in southern Australia several decades ago (Jahnke 1978), and samples of $M$. ectocarpii were confirmed by Maier et al. (2000) on local populations of Ectocarpus siliculosus.

D. antarctica is able to raft long distances and has even been known to wash up on Australian shores, $1000 \mathrm{~s}$ of $\mathrm{km}$ from the nearest source population (Moore \& Cribb 1952). We hypothesised that Maullinia would thus have a broad distribution and that distant populations - possibly even those affecting other host species - would show evidence of connectivity. We further hypothesised that infection prevalence would vary along latitudinal gradients, with the greatest infection prevalence toward the northern limits of the hosts' ranges, where kelps are most physiologically stressed (e.g. Tala et al. 2016). We tested these hypotheses using ecological and genetic surveys of infected Durvillaea along the southern Australian and southern-central Chilean coasts.

\section{MATERIALS AND METHODS}

\section{Sample collection}

Sampling was conducted in Australia, Chile and sub-Antarctic Marion Island (Fig. 1). Australian sampling and surveys were carried out at 5 sites: Tathra, City Rock, Mallacoota, Cape Conran and Cape Schanck. In Chile, intertidal sampling was carried out at 8 sites: Pichicuy, Quintay, Pichilemu, Curanipe, Queule, Chaihuin, Hua Huar and Pumillahue. Infected tissue from Marion Island was collected opportunistically from 3 sites: Macaroni Bay, Trypot Beach and Rockhopper Bay. All sampling occurred in late spring and summer 2015/16. For visual quantification of infections in the field (Australia and Chile only), morphological identification of galls was based on descriptions in Aguilera et al. (1988), Jahnke (1978) and Goecke et al. (2012). Infection prevalence was quantified along a series of $10 \mathrm{~m}$ transects. Numbers of kelp transect ${ }^{-1}$ varied within and between sites, leading to differing sample sizes at each location (Table 1). Three transects site ${ }^{-1}$ were surveyed in Australia, and 3 to 5 transects site ${ }^{-1}$ were surveyed in Chile, depending on the extent and accessibility of 


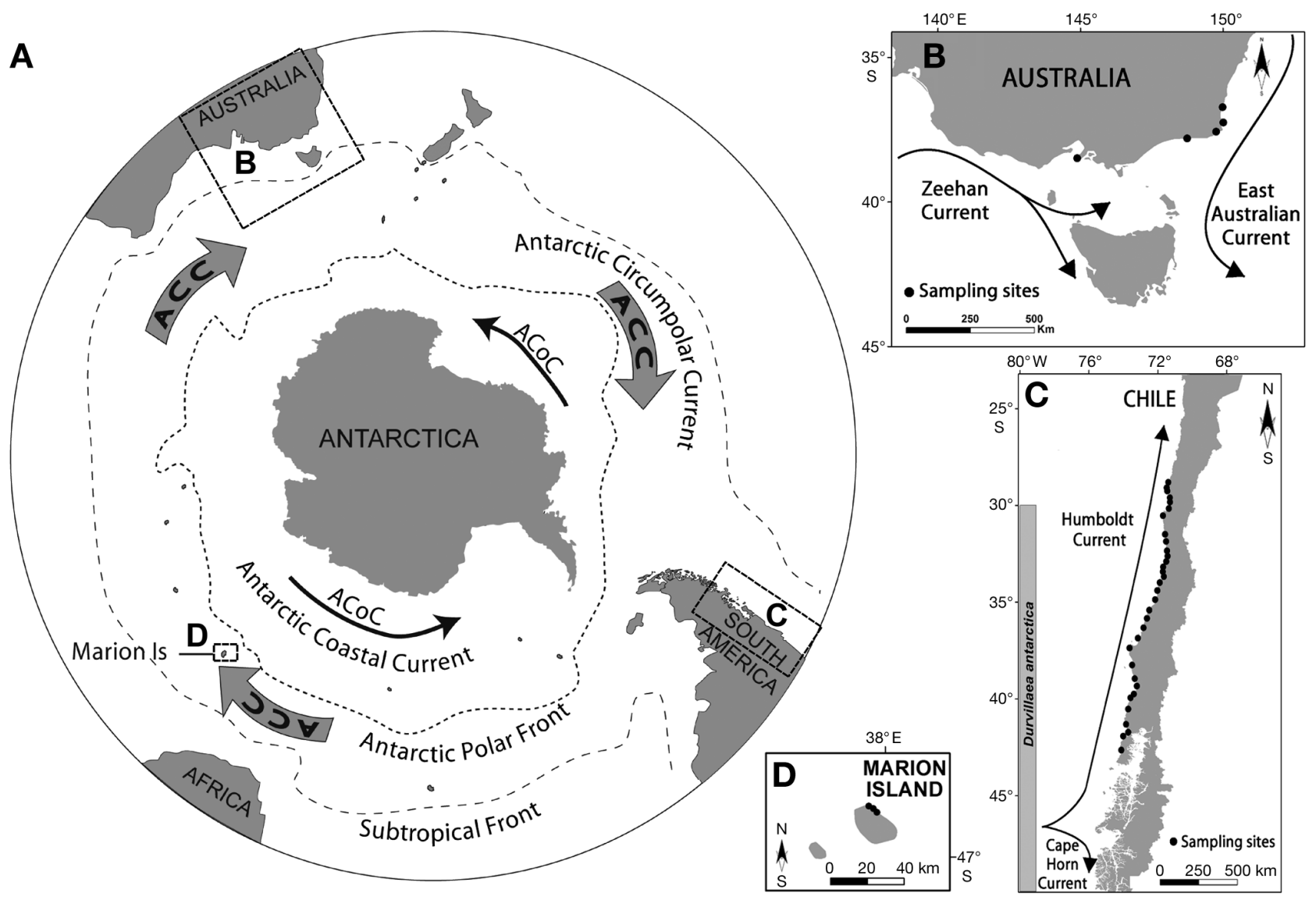

Fig. 1. (A) Global projection of Antarctica and sub-Antarctic areas, showing the main marine currents and the location of sub-Antarctic Marion Island. The study areas on (B) the Australian coast, (C) the Chilean coast and (D) Marion Island and their local marine currents are also indicated. Black dots indicate sampling and survey sites. The geographic distribution of Durvillaea antarctica along the Chilean coast is indicated

Table 1. Sampling and sequencing information for intertidal sites visited

\begin{tabular}{|c|c|c|c|c|c|c|}
\hline Country & Site & $\begin{array}{c}\text { Individuals } \\
\text { surveyed }\end{array}$ & $\begin{array}{l}\text { Samples } \\
\text { collected }\end{array}$ & $\begin{array}{l}\text { Samples } \\
\text { amplified }\end{array}$ & $\begin{array}{l}\text { Samples } \\
\text { sequenced }\end{array}$ & $\begin{array}{c}\text { Number of } \\
\text { unique sequences }\end{array}$ \\
\hline \multirow[t]{5}{*}{ Australia } & Tathra & 63 & 8 & 4 & 4 & 2 \\
\hline & City Rock & 63 & 2 & 2 & 2 & 1 \\
\hline & Mallacoota & 79 & 9 & 9 & 9 & 1 \\
\hline & Cape Conran & 64 & 7 & 4 & 3 & 1 \\
\hline & Cape Schanck & 125 & 12 & 7 & 4 & 2 \\
\hline \multirow[t]{8}{*}{ Chile } & Pichicuy & 112 & 4 & 1 & 1 & 1 \\
\hline & Quintay & 133 & 17 & 8 & 4 & 2 \\
\hline & Pichilemu & 158 & 10 & 4 & 4 & 4 \\
\hline & Curanipe & 76 & 4 & 3 & 2 & 1 \\
\hline & Queule & 164 & 2 & 2 & 2 & 2 \\
\hline & Chaihuin & 144 & 24 & 14 & 5 & 3 \\
\hline & Hua Huar & 317 & 24 & 13 & 7 & 4 \\
\hline & Pumillahue & 145 & 32 & 18 & 7 & 4 \\
\hline
\end{tabular}

kelp beds. Transect lines were laid on rocky platforms partially or completely emergent at low tide. As Durvillaea species often inhabit fragmented rocky platforms composed of a number of reefs separated by water, it was not always possible to lay transects parallel to one another. Rather, they were laid on the edges of such platforms, separated by at least $2 \mathrm{~m}$ if on the same platform, where kelp are likely to experience similar exposure to environmental factors between sites. The number of healthy and diseased 
kelp were counted on each transect, with only those plants whose stipe intercepted a transect being considered. To confirm the presence of Maullinia at each site (as other organisms are known to produce galllike structures on D. antarctica in Chile; Saavedra 2011), and to enable phylogeographic analyses, tissue samples for genetic analysis were collected from galls from every third infected kelp. Samples were placed in a $50 \mathrm{ml}$ Eppendorf tube filled with $70 \%$ ethanol, with the alcohol replaced once after several hours. After 24-48 h, samples were either air-dried on clean paper towel or in an oven at $60^{\circ} \mathrm{C}$ for several hours, then stored with silica gel.

In order to determine the rafting potential of Maullinia, we examined recently stranded specimens of $D$. antarctica on 33 sandy and boulder beaches along the Chilean coast $\left(28-42^{\circ} \mathrm{S}\right)$ during austral winters and summers of 2 consecutive years (2014-2015) across the benthic and pelagic geographical range of the continental clade of D. antarctica (Fig. 1C). Within each beach, recently stranded individuals of $D$. antarctica were collected on foot following the coastline along the most recent flotsam lines (i.e. the last 2-3 high tides). For each complete kelp individual (including holdfast and fronds), the presence of galls of Maullinia was determined, and the frequency of infected specimens was calculated. The details of the sampling protocols used for collection and measurement of stranded specimens of D. antarctica are described in López et al. (2017a).

\section{Genetic analyses}

Small $(<2 \mathrm{~mm})$ pieces of infected, dried kelp tissue were excised using a scalpel sterilised with alcohol and flame, and DNA was extracted following the standard Chelex ${ }^{\complement}$ protocol (Walsh et al. 1991). Extractions were diluted 1:100 in MilliQ water to reduce the possibility of alginates blocking PCR processes (see Wilson et al. 2016). PCR amplification was conducted in a $20 \mu$ l solution, comprising $12.5 \mu$ l MilliQ water, $0.2 \mu \mathrm{l}$ each of forward and reverse $10 \mathrm{mM}$ primers, $4 \mu \mathrm{l}$ of $1 \mathrm{mM}$ dNTPS, $0.1 \mu \mathrm{l}$ of PerfectTaq polymerase, $2 \mu \mathrm{l}$ of PerfectTaq buffer (5Prime) and $1 \mu \mathrm{l}$ of diluted DNA extraction. Maullinia-specific primers that would not amplify host DNA were used: Mau2F (5' ACGGGTACGAGGGACGTGGG) and Mau9R (5' TGCATCAGTGTAGCGAGCGT) (Goecke et al. 2012). These primers amplified part of the $18 \mathrm{~S}$ nuclear ribosomal gene, which is used for taxonomic identifications, descriptions of variation between populations of differing geographical origin and analyses of protist phylogenetic relationships (Pawlowski et al. 2012, Hadziavdic et al. 2014, Wang et al. 2014). PCRs were run in an Eppendorf Mastercycler (Epgradient S) using the Maullinia Touchdown protocol of Goecke et al. (2012). PCR products were purified using a QIAQuick PCR Purification Kit (Qiagen) to be sent for sequencing at the University of Otago's Genetic Analysis Services (Otago, New Zealand), using an Applied Biosystems 3730xl capillary sequencer (Thermo Fisher Scientific).

\section{Phylogenetic analyses}

Sequences were aligned and trimmed, and ambiguities were corrected in Geneious 6.1.8 (Kearse et al. 2012). Two published sequences, i.e. 1 from $M$. ectocarpii on Ectocarpus alga in Chile and 1 from Maullinia sp. (now M. braseltonii) on D. antarctica in Chile, were included in the alignment alongside related outgroup sequences from GenBank (Phagomyxa odontellae AF310904; Spongospora subterranea AF310899). Haplotype networks were created using TCS 1.21 (Clement et al. 2000).

The most appropriate model of DNA evolution was determined using jModeltest2 (Darriba et al. 2012) according to Akaike's information criterion adjusted for small sample sizes (AICc). Model parameters were: $\mathrm{TrN}+\mathrm{G}$ (gamma shape 0.4240 , proportion inv sites 0 ). The maximum likelihood (ML) phylogenetic tree was constructed in PhyML 3.0 (Guindon et al. 2010) with support for nodes determined using 1000 bootstrap iterations. The Bayesian phylogenetic tree was constructed in MrBayes 3.2.0 (Ronquist \& Huelsenbeck 2003) with Markov chain Monte Carlo (MCMC) searches of 4 chains and burn-in of 10000 trees. Trees were sampled every 100 generations for a total of 5000000 generations.

\section{Ecological analyses}

Testing for latitudinal effects in infection prevalence using a binomial model showed over-dispersion, so a negative binomial distribution with a logarithm link function (Lawless 1987) was used instead. Modelling was based on the number of infected kelps transect $^{-1}$ by latitude, offset by the natural log of total kelp due to variability in total numbers of kelp transect $^{-1}$. Data from Chile and Australia were tested separately. Likewise, to verify the relationship of the frequency of stranded individuals of $D$. antarctica with $M$. braseltonii and latitude, analyses were per- 
formed using generalised linear models (GLMs) for the total and for each field survey separately, offset by the natural log of the total number of sampled kelps. The model used was:

model $=$

glm.nb (count of infected individuals $\sim$ latitude + offset $(\log ($ total individuals per beach $))$, data $=$ data $)$.

All statistical tests were done with R 3.4., using the 'MASS' and 'visreg' packages (R Development Core Team 2017).

\section{RESULTS}

Infections of Maullinia braseltonii in Chile and Marion Island were similar in shape, size and colour to those described by Goecke et al. (2012) and Aguilera et al. (1988); gall diameters ranged from 2 to $15 \mathrm{~cm}$. Infections in Australia were smaller than their Chilean counterparts, ranging in diameter from 1 to $5 \mathrm{~cm}$. Infected tissue had a warty appearance, raised and tougher than surrounding areas and often showing concentric rings of discolouration.

Sequencing confirmed Maullinia infections on Durvillaea at all intertidal sites visited in Australia (Fig. 2) and Chile (Fig. 3), as well as from the 3 Mar-

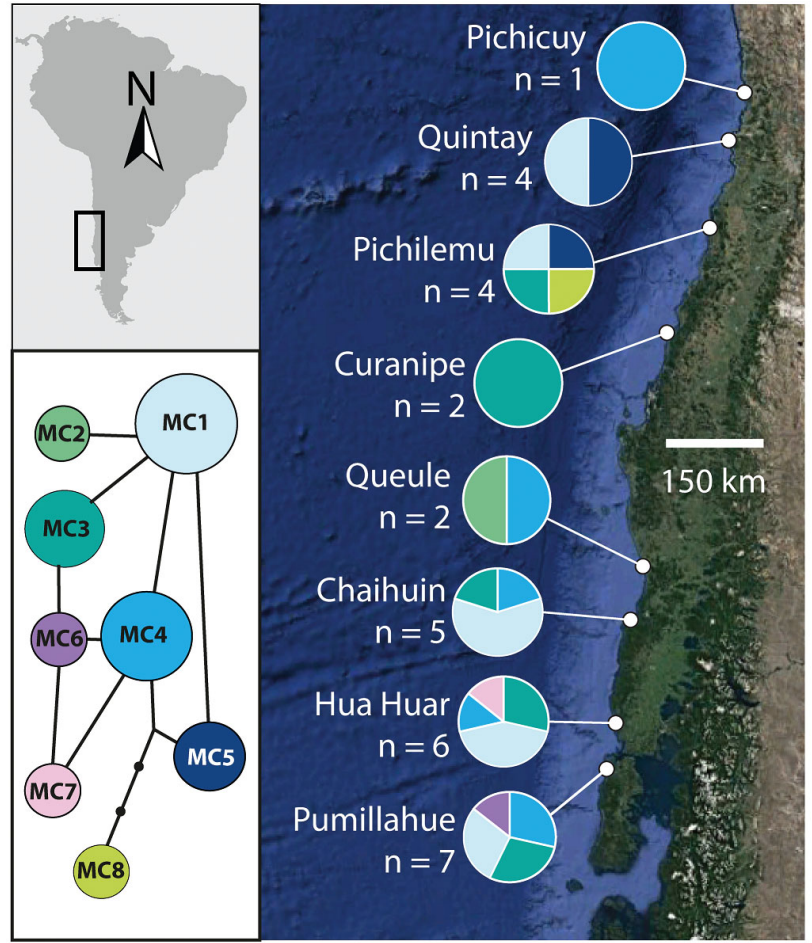

Fig. 3. Sampling locations in Chile. The proportion of Maullinia haplotypes at each sampled site is shown. Haplotype network at left shows the relative prevalence of Maullinia haplotypes (circle size), with black dots representing hypothetical undetected haplotypes

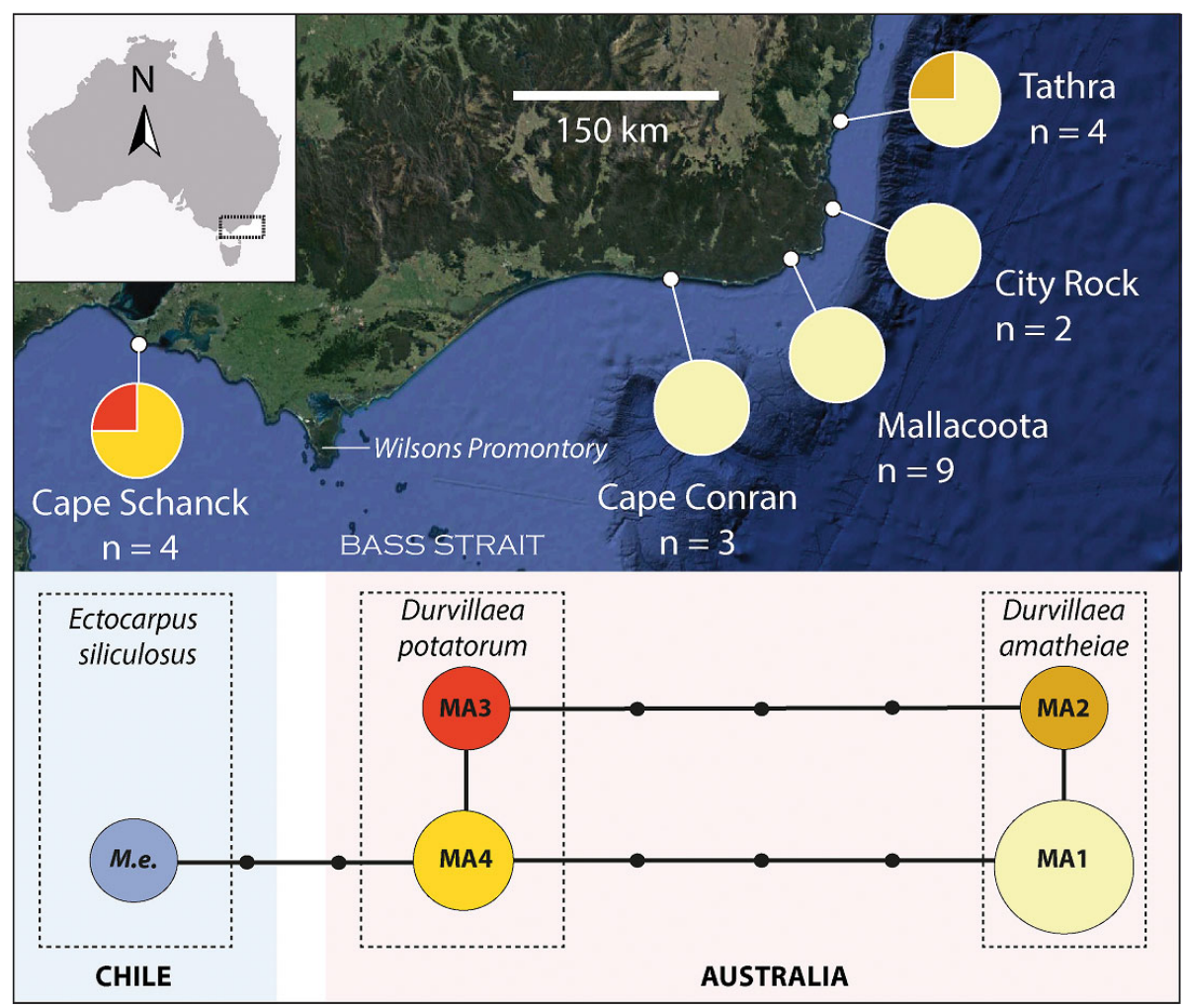

Fig. 2. Sampling locations in Australia. The proportion of Maullinia haplotypes at each sampled site is shown. Haplotype network below shows host species (dashed boxes), and relative prevalence of Maullinia haplotypes (circle size); black dots represent hypothetical undetected haplotypes. Previously published sequences of M. ectocarpii (M.e.) from Ectocarpus siliculosus in Chile from Maier et al. (2000) were closely related to Australian Maullinia samples from Durvillaea 
ion Island sites. Successful amplification of tissue collected from galls was not always achieved ( 60\% success in Chile, $70 \%$ in Australia, 50\% Marion Island; Table 1), but some amplification failure is common in PCR, particularly for algal extractions that include inhibitors (Wilson et al. 2016). Furthermore, the primers we used were developed for $M$. ectocarpii, and although they also amplify $M$. braseltonii, there might be other Maullinia or related phytomyxean species affecting these kelp populations that our primers could not detect. In an attempt to improve our capacity to detect other species and resolve fine-scale structure for Maullinia, we designed and assayed a range of other primers for alternative markers based on available sequences from other genera (though few such sequences were available), but none performed well and all were therefore discarded (see Table S1 in the Supplement at www.int-res.com/articles/suppl/m583p095 _supp.pdf). New sequences recently published for M. ectocarpii (see Schwelm et al. 2016) may assist in future primer development. Based on the morphological similarity of amplified and non-amplified infections, and the confirmation of Maullinia at all sites, we considered visual field identifications adequate for analyses of infection prevalence. Each unique sequence generated during this research was deposited in GenBank (accessions MF872442MF872453).

\section{Phylogenetic analyses}

We obtained Maullinia sequences from 54 samples from 8 intertidal sites in Chile and 5 intertidal sites in Australia, with 12 distinct sequences detected (8 sequences from 32 samples in Chile, and 4 sequences from 22 samples in Australia). Ten samples were sequenced from Marion Island. The 18S ML and Bayesian phylogenetic trees showed strong consistency in overall topology and branch support (Fig. 4). No sequences were shared between Australia and Chile, although the published $M$. ectocarpii sequence of Maier et al. (2000) from Chile was closely related to Australian Maullinia (Fig. 2). All sequences from Marion Island were identical to sequence MC4 from $M$. braseltonii, which is widespread in Chile (Figs. $3 \& 4$ ). There was up to $0.3 \%$ divergence (uncorrected $\mathrm{P}$ distance) within each country, and $2.4-2.6 \%$ between the 2 countries.

Australian sequences appeared to show separation into eastern and western groups, with sequence MA1 being present at all eastern sites and MA4 being

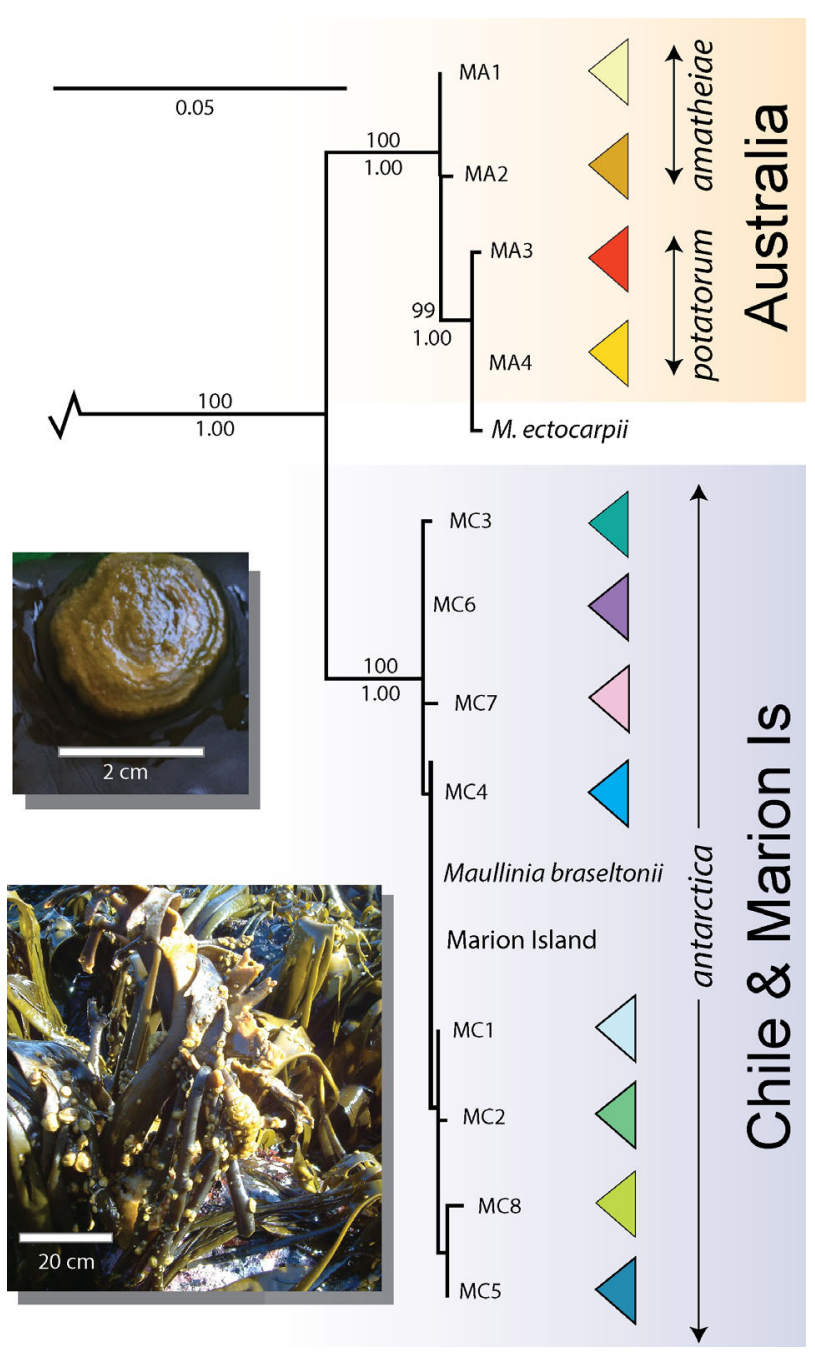

Fig. 4. Maximum likelihood phylogeny of Maullinia samples collected in Australia, Chile and Marion Island. Haplotype colours correspond to those in Figs. 2 \& 3. Bootstrap values $>75 \%$ are shown above major branches and Bayesian posterior probabilities below. Outgroups have been trimmed for clarity. Two previously published sequences of Maullinia (M. ectocarpii from an Ectocarpus host in Chile, Maier et al. 2000; and $M$. braseltonii from a Durvillaea host in Chile, Goecke et al. 2012) were included. To the right of the tree, vertical text indicates host Durvillaea species and geographic region. Top inset photo: relatively small Maullinia gall on D. antarctica tissue from Quintay, Chile. Bottom inset photo: galls on D. antarctica at Marion Island in 2007

(observed a decade prior to this genetic research)

most abundant at Cape Schanck (Fig. 2). No seuences were shared between eastern and western areas, corresponding to the geographical distributions of different host species described by Weber et al. (2017); however, a greater number of samples would be needed to confirm if this trend was not simply a result of the relatively small number of pathogen sequences. 
In Chile, the 3 most abundant sequences (MC1, MC3 and MC4) were found across large parts of the host's range, from the southernmost to northern sampled regions. Sequence MC4 exactly matched the published sequence of Maullinia sp. (Goecke et al. 2012; now M. braseltonii: Murúa et al. 2017) and sequences from Marion Island (Fig. 4). There was greater overall diversity in the Chilean than the Australian samples, but there was also a strong positive relationship between number of unique sequences detected and number of samples sequenced at sites.

\section{Latitudinal effects}

For Australia, GLMs supported latitude as being a significant predictor of infection prevalence $(\mathrm{p}=$ 0.015), with numbers of infected kelp increasing towards higher latitudes (Fig. 5). For Chile, infection prevalence also appeared to increase with latitude, but the relationship was not significant. Data from Quintay, however, had a marked influence on the strength of the relationship, and when Quintay data were excluded, latitude was a strong predictor $(\mathrm{p}<$ 0.001) of infection prevalence.

In the case of recently stranded individuals of $D$. antarctica from continental Chile, a positive and significant relationship between the frequency of individuals infected with $M$. braseltonii and latitude was observed for the total of all surveys ( $p<0.001)$, as well as for each individual survey (winter 2014, p = 0.002; summer 2014/2015, p < 0.001; winter 2015, p < 0.001; summer 2015/2016, p =0.005; Fig. 6).

\section{DISCUSSION}

Our results confirm, for the first time, infections of Maullinia ectocarpii on populations of Durvillaea (D. potatorum and D. amatheiae) in Australia. Different parasite lineages were found associated with each algal host species, suggesting some host specificity. Infections of $M$. braseltonii were found on $D$. antarctica throughout central Chile and at Marion Island more than $8000 \mathrm{~km}$ away, indicating that recent long-distance dispersal of the parasite has occurred, presumably by dispersal with its buoyant algal host.

Our hypothesis that infections would be greatest toward the northern range limits of the hosts was not supported by our results. Environmental gradients do appear to influence infection levels, however, as we observed a pattern of increased parasite prevalence with increasing latitude.

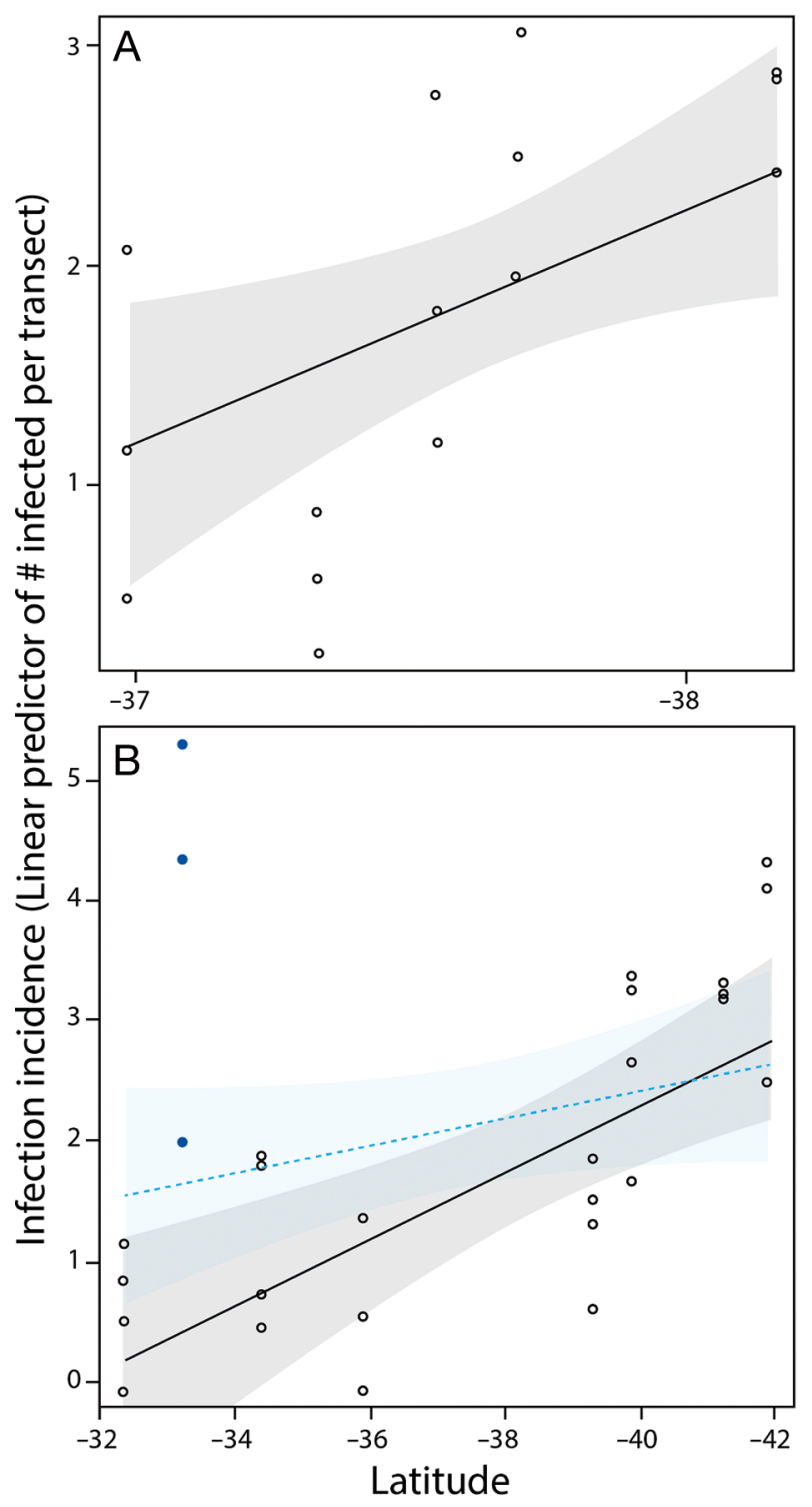

Fig. 5. Relationship of latitude to infection prevalence (number of infected kelp transect ${ }^{-1}$, offset by the natural log of total kelp) in (A) Australia and (B) Chile. Trendlines are presented with $95 \%$ confidence intervals (shaded). For Chile, infections recorded from transects at a single site, Quintay (indicated by filled blue dots), had a strong influence on the trend (dashed blue line). When Quintay data were removed from analyses, the general trend of decreasing infection with decreasing latitude was strongly emphasised (black line)

\section{Genetic trends for Maullinia}

The 2 deeply divergent (2.4-2.6\%, Fig. 4) clades appear to represent distinct species: $M$. ectocarpii in Australia and $M$. braseltonii in Chile and Marion Island.

Within-country genetic patterns, with identical sequences detected at sites separated by hundreds of 


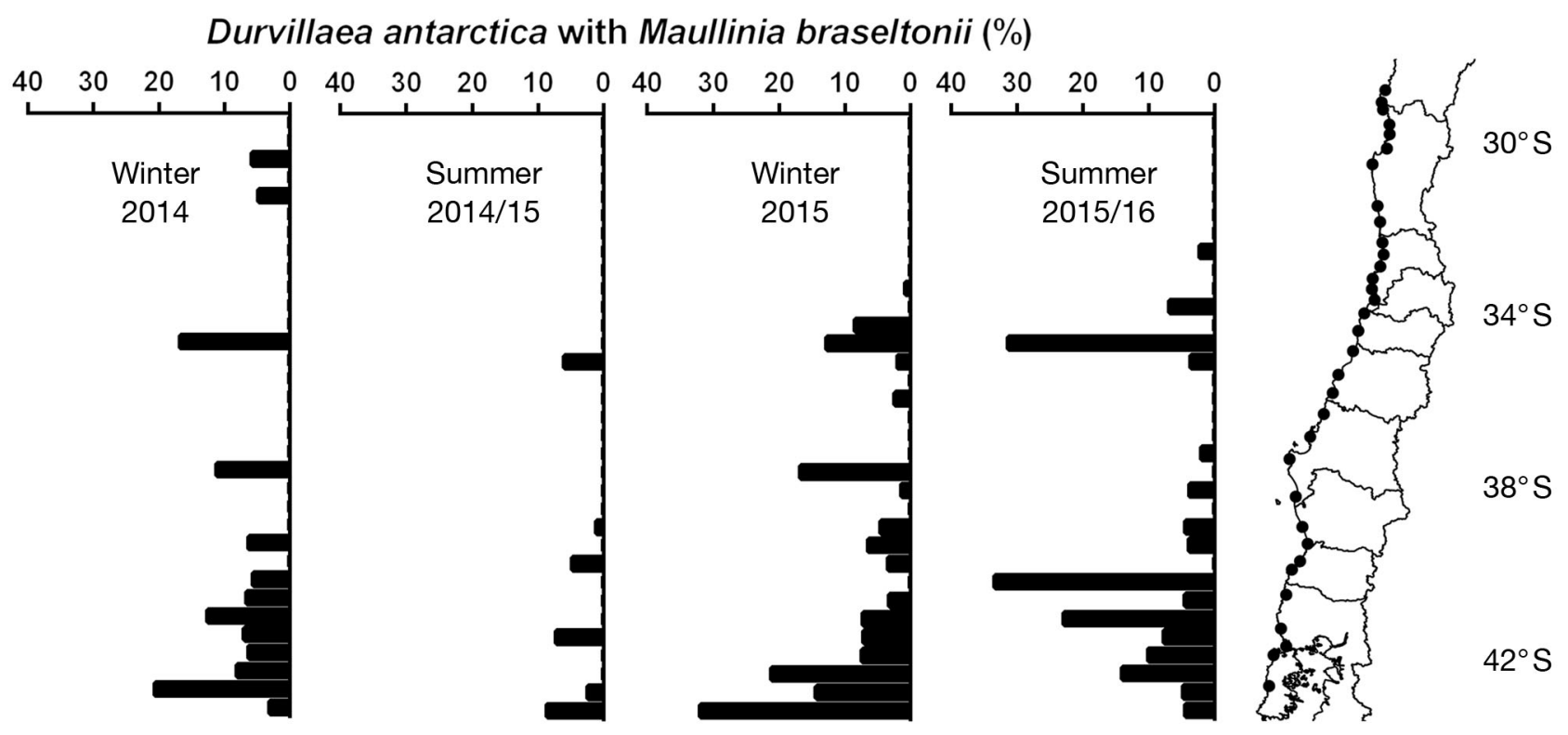

Fig. 6. Percentages of stranded individuals of Durvillaea antarctica with Maullinia braseltonii found in surveys on sandy and boulder beaches from $28^{\circ}$ to $42^{\circ} \mathrm{S}$ along the Chilean coast, during winters and summers of 2014-2016

kilometres (Figs. 2 \& 3), indicate that coastal dispersal of this parasite probably occurs, perhaps through both rafting of infected tissue and larval/zoosporic stages. The Chilean coast is affected by a number of oceanic current systems, in particular the Humboldt Current, which transports cool water towards the equator, and the Peru Countercurrent, which transports warmer subtropical water to the south (Silva et al. 2009). These currents affect a range of organisms along the Chilean coast (Peters \& Breeman 1993), including kelp rafts (Rothäusler et al. 2011), with similar currents affecting organismal larval stages (Gaylord \& Gaines 2000). As such, the lack of strong phylogeographic structure in Chile across more than $1000 \mathrm{~km}$ of coastline (Fig. 3) may be attributable to passive dispersal mechanisms (see also Haye et al. 2012). Likewise, a recent study on the red seaweed Gelidium lingulatum, which is frequently found growing in D. antarctica holdfasts, showed that some haplotypes were common in southern as well in northern localities (López et al. 2017b).

In contrast, coastal current systems in south-eastern Australia are likely to maintain the separation of pathogen populations to the east and west of southern Victoria. Indeed, our results show considerable $(0.3 \%, 18 \mathrm{~S})$ divergence among eastern and western populations of M. ectocarpii in Australia. The eastern and western lineages appear to align with the disjunct distributions of hosts $D$. potatorum and $D$. amatheiae (Fig. 2), suggesting there may be hostspecificity and/or other processes maintaining bio- geographic structure in both hosts and pathogens. Although our sample sizes and sampling range were too limited in this study to allow detailed analysis of such fine-scale structure, a biogeographic break across Wilson's Promontory in southern Victoria would be consistent with patterns observed in a wide range of other taxa (O'Hara \& Poore 2000, Waters 2008), including the host genus Durvillaea (Fraser et al. 2009, Weber et al. 2017). While this biogeographic pattern is broadly thought to be a historical outcome of vicariant processes related to the Bassian Isthmus land bridge during the Last Glacial Maximum (Fraser et al. 2009), it is thought to have been maintained through modern oceanographic systems and through density-dependent ecological processes (Waters et al. 2005, 2013).

Identical $M$. braseltonii sequences were obtained from Chile and from Marion Island (more than $8000 \mathrm{~km}$ away), suggesting that long-distance dispersal of the parasite has recently occurred. Furthermore, although Maullinia collected from Durvillaea in Australia and in Chile formed distinct geographic clades, the similarity of $M$. ectocarpii sequences from Durvillaea in Australia, and from Ectocarpus in Chile, also supports long-distance dispersal of Maullinia. The Antarctic Circumpolar Current connects the sub-Antarctic islands and the major continents of the Southern Hemisphere (Fig. 1), and detached macroalgae floating eastward in the path of this ocean highway have been inferred to have transported a range of rafting organisms (including another algal 
parasite, Herpodiscus durvillaeae: Fraser \& Waters 2013) among distant landmasses (e.g. Helmuth et al. 1994, Nikula et al. 2010, 2013, Fraser et al. 2011, Cumming et al. 2014). Interestingly, the strong link between $M$. braseltonii from both central Chile and the sub-Antarctic (Marion Island) is not reflected in the kelp genetics, as these 2 areas have distinct clades of D. antarctica (Fraser et al. 2010). That we nonetheless here infer movement of the parasite with its buoyant host between the sub-Antarctic and central Chile supports suggestions that phylogeographic structure in $D$. antarctica results from densitydependent processes that maintain structure even with frequent dispersal (Waters et al. 2013).

Despite some evidence for host-specificity (with different Maullinia lineages detected on each Durvillaea species), our data suggest this parasite readily shifts hosts, much like other phytomyxids (Neuhauser et al. 2014). Indeed, infections of M. ectocarpii in Australia have previously been recorded on the alga E. siliculosus (Maier et al. 2000). Host shifting may allow parasites to survive for long time periods in environments with ephemeral hosts or adverse environmental conditions (Neuhauser et al. 2014), as infections on one species can supplement those on another.

\section{Latitudinal effects on infection prevalence}

Our hypothesis that infection prevalence would increase towards the hosts' northern latitudinal range limits due to increasing physiological stress was not supported. However, the infection prevalence was instead found to increase towards higher latitudes, or the southern range limit of the host (Fig. 5). For Chile, this effect was strongest when data from Quintay, where prevalence was remarkably high, were removed. Quintay might have unusually high infection levels due to an environmental stressor, such as pollution; pollution has increasingly been implicated in outbreaks of marine disease (Li et al. 2010, Saavedra 2011), including for algae (Buschmann et al. 2014), and Quintay was the closest site to Valparaiso, the most densely populated coastal city within our sampled range in Chile. The observed trend in multiyear samplings of stranded individuals of $D$. antarctica confirms the pattern that Maullinia infection rates tend to increase with latitude, although there may be some temporal variability (Fig. 6).

Our observations of increased Maullinia infections at higher latitudes are consistent with the suggestion by Aguilera et al. (1988) that infections within this pathosystem might intensify towards the south in Chile. Despite our low sample numbers and limited sampling range, geographic variability in infection prevalence suggests parasite susceptibility to local conditions (Poulin et al. 2012), and several possibilities could explain the observed patterns, as follows.

\section{Population densities}

Pathogen transmission can increase with higher densities and greater connectivity between hosts (Poulin et al. 2012, Izhar \& Ben-Ami 2015). Durvillaea species in Australia are known to transition from being a relatively rare intertidal element at Tathra (the northern range limit) to a dominant habitatforming species on rocky intertidal platforms in Tasmania (southern part of the species' range) (Millar 2007). D. antarctica in Chile experiences competition from other algal species including Lessonia spp. towards its northern latitudinal range limit, reducing its density and prevalence, but is more abundant toward the south (Santelices et al. 1980), where abundant rafting populations of large adult plants have also been observed (López et al. 2017a). In this research, we sampled southward from the northern range limits of Durvillaea in Chile and Australia, such that more southern populations also had higher host densities, which could have led to increased pathogen transmission, and thus infection levels, at high latitudes.

\section{Temperature effects}

Although we hypothesised that hosts would prove most susceptible to infection towards their range limits due to higher physiological stress, these hosts might actually have greater resistance due to their ability to survive in marginal conditions. Although ecotype effects have not been demonstrated previously for Durvillaea, they have been inferred for other algal species including the kelp Undaria pinnatifida (Gao et al. 2013), for which populations varied in temperature resistance depending on the latitude from which samples were collected. Such ecotypes often develop due to strong environmental patterns, the most pervasive of which are temperature gradients in the marine intertidal realm (Cruces et al. 2013). Along the Chilean coast, mean surface water temperatures range from around $18^{\circ} \mathrm{C}$ in the north to $6-8^{\circ} \mathrm{C}$ in the far south (Locarnini et al. 2013), and within the region that we sampled, temperatures 
range from around $14^{\circ} \mathrm{C}$ (winter) to $19^{\circ} \mathrm{C}$ (summer) in the north to $12^{\circ} \mathrm{C}$ (winter) to $17^{\circ} \mathrm{C}$ (summer) in the south (Tala et al. 2016). Such latitudinal temperature changes can present different physiological challenges for intertidal taxa (Tala et al. 2016), and thus might also lead to geographic genetic variation in the host kelp.

Our detection of identical sequences of $M$. braseltonii in both central Chile and in the sub-Antarctic suggests that at least some lineages of the parasite can survive at a range of temperatures, but their virulence might increase, and/or host resistance might decrease, in cooler waters. The relationship between latitude and water temperature is well-recognised along a range of coastlines (Tuya et al. 2012), with both Australia and Chile showing a decrease in mean water temperature towards higher latitudes. Temperature effects have been shown in a range of terrestrial and marine pathosystems (Case et al. 2011), acting on both host and parasite. For Durvillaea species, increasing temperature has been associated with increased physiological stress (Cruces et al. 2013), and while such effects remain unquantified for Maullinia species (Neuhauser et al. 2011), the parasite might be similarly affected. For some marine species, larvae have been found to persist for shorter periods at sea when exposed to higher temperatures (Bradbury et al. 2008, Cowen \& Sponaugle 2009), limiting their ability to disperse and, in the case of parasites, infect new hosts. As such, at cooler temperatures Maullinia might be more virulent and have improved dispersal and survival of zoospores, as also suggested by the tendency for slightly higher infestation rates during winter months (see Fig. 6). In the face of warming sea temperatures, this may thus counteract the virulence of the parasite, pushing its range south to cooler areas.

\section{CONCLUSIONS}

Understanding the factors underpinning outbreaks of marine disease is essential for appropriate monitoring and management of marine ecosystems into the future. Our research emphasises the value of combining molecular and ecological approaches in order to describe pathosystem dynamics, particularly for micro-organisms whose visual identification can prove challenging.

Previous research had only shown $M$. braseltonii infecting Durvillaea hosts in central Chile. We have demonstrated that the parasitic genus infects multiple host species within the genus Durvillaea in Chile, Marion Island and Australia. Further, these popula- tions are probably connected via dispersal of the parasite with floating macroalgal hosts. The presence of this parasite on brown algal hosts across the Pacific and Indian Oceans would suggest a high likelihood of the pathosystem extending to other locations. Variable prevalence over latitudinal ranges suggests that environmental or ecological factors shape infection patterns, and these data may assist in understanding how the pathogen will respond to a changing climate. A broader study that assesses the phylogeography of Maullinia from other landmasses with $D$. antarctica populations (such as New Zealand and other sub-Antarctic islands) would help to provide a clearer picture of the dispersal potential of this pathogen. Molecular analyses using a greater number of markers, and modelling of a wide range of environmental factors, could also provide greater insights into how Maullinia spp. infections will change under future climate scenarios.

Acknowledgements. We thank Frank Gleason, Sigrid Neuhauser, Fadia Tala, Oscar Pino, Vieia Villalobos and Amanda Padovan for theoretical, field and laboratory assistance and Hwan-Jin Yoon for statistical advice. Peter Ryan, Stefan Schoombie and Janine Schoombie kindly collected the samples from Marion Island. This project was funded by Fondecyt grant (CONICYT-FONDECYT 1131082), the Fenner School of Environment and Society at the Australian National University and a PhD fellowship Beca CONICYTPCHA/DoctoradoNacional/2014-21140010 to B.A.L.

\section{LITERATURE CITED}

Aguilera M, Rivera PJ, Westermeier R (1988) Presencia de hongos plasmodiophorales en plantas de Durvillaea antarctica (Cham.) Hariot (Phaeophyta, Durvilleaceae) del sur de Chile. Gayana Bot 45:337-343

Andrews JH (1976) The pathology of marine algae. Biol Rev Camb Philos Soc 51:211-252

* Bradbury IR, Laurel B, Snelgrove PVR, Bentzen P, Campana SE (2008) Global patterns in marine dispersal estimates: the influence of geography, taxonomic category and life history. Proc R Soc B 275:1803-1809

Buschmann AH, Prescott S, Potin P, Faugeron S and others (2014) The status of kelp exploitation and marine agronomy, with emphasis on Macrocystis pyrifera in Chile. Adv Bot Res 71:161-188

Carius HJ, Little TJ, Ebert D (2001) Genetic variation in a host-parasite association: potential for coevolution and frequency-dependent selection. Evolution 55:1136-1145

Case RJ, Longford SR, Campbell AH, Low A, Tujula N, Steinberg PD, Kjelleberg S (2011) Temperature induced bacterial virulence and bleaching disease in a chemically defended marine macroalga. Environ Microbiol 13: 529-537

Clement M, Posada D, Crandall KA (2000) TCS: a computer program to estimate gene genealogies. Mol Ecol 9: 1657-1659

Collinge SK, Ray C, Cully JF Jr, Ostfeld R, Keesing F, Eviner $\mathrm{V}$ (2008) Effects of disease on keystone species, domi- 
nant species, and their communities. In: Richard Ostfeld FK, Valerie Eviner (eds) Infectious disease ecology. Princeton University Press, Princeton, NJ, p 129-144

Cowen RK, Sponaugle S (2009) Larval dispersal and marine population connectivity. Annu Rev Mar Sci 1:443-466

Cruces E, Huovinen P, Gómez I (2013) Interactive effects of UV radiation and enhanced temperature on photosynthesis, phlorotannin induction and antioxidant activities of two sub-Antarctic brown algae. Mar Biol 160:1-13

Cumming RA, Nikula R, Spencer HG, Waters JM (2014) Transoceanic genetic similarities of kelp-associated sea slug populations: long-distance dispersal via rafting? J Biogeogr 41:2357-2370

* Darriba D, Taboada GL, Doallo R, Posada D (2012) jModelTest 2: more models, new heuristics and parallel computing. Nat Methods 9:772

Eggert A, Peters AF, Küpper FC (2010) The potential impact of climate change on endophyte infections in kelp sporophytes. In: Seckbach J, Einav R, Israel A (eds) Seaweeds and their role in globally changing environments, Book 15. Springer, Dordrecht p 139-154

* Fraser CI, Waters JM (2013) Algal parasite Herpodiscus durvillaeae (Phaeophyceae: Sphacelariales) inferred to have traversed the Pacific Ocean with its buoyant host. J Phycol 49:202-206

Fraser CI, Spencer HG, Waters JM (2009) Glacial oceanographic contrasts explain phylogeography of Australian bull kelp. Mol Ecol 18:2287-2296

Fraser CI, Winter DJ, Spencer HG, Waters JM (2010) Multigene phylogeny of the southern bull-kelp genus Durvillaea (Phaeophyceae: Fucales). Mol Phylogenet Evol 57: 1301-1311

Fraser CI, Nikula R, Waters JM (2011) Oceanic rafting by a coastal community. Proc R Soc B 278:649-655

Gachon CMM, Strittmatter M, Müller DG, Kleinteich J, Küpper FC (2009) Detection of differential host susceptibility to the marine oomycete pathogen Eurychasma dicksonii by real-time PCR: Not all algae are equal. Appl Environ Microbiol 75:322-328

* Gachon CMM, Sime-Ngando T, Strittmatter M, Chambouvet A, Kim GH (2010) Algal diseases: spotlight on a black box. Trends Plant Sci 15:633-640

Gao X, Endo H, Taniguchi K, Agatsuma Y (2013) Genetic differentiation of high-temperature tolerance in the kelp Undaria pinnatifida sporophytes from geographically separated populations along the Pacific coast of Japan. J Appl Phycol 25:567-574

*aylord B, Gaines SD (2000) Temperature or transport? Range limits in marine species mediated solely by flow. Am Nat 155:769-789

*Gleason FH, van Ogtrop F, Lilje O, Larkum AWD (2013) Ecological roles of zoosporic parasites in blue carbon ecosystems. Fungal Ecol 6:319-327

Goecke F, Wiese J, Núñez A, Labes A, Imhoff JF, Neuhauser S (2012) A novel phytomyxean parasite associated with galls on the bull-kelp Durvillaea antarctica (Chamisso) Hariot. PLOS ONE 7:e45358

Guindon S, Dufayard JF, Lefort V, Anisimova M, Hordijk W, Gascuel O (2010) New algorithms and methods to estimate maximum-likelihood phylogenies: assessing the performance of PhyML 3.0. Syst Biol 59:307-321

Hadziavdic K, Lekang K, Lanzen A, Jonassen I, Thompson EM, Troedsson C (2014) Characterization of the $18 \mathrm{~S}$ rRNA gene for designing universal eukaryote specific primers. PLOS ONE 9:e87624
Haye PA, Varela AI, Thiel M (2012) Genetic signatures of rafting dispersal in algal-dwelling brooders Limnoria spp. (Isopoda) along the SE Pacific (Chile). Mar Ecol Prog Ser 455:111-122

*Helmuth B, Veit RR, Holberton R (1994) Long-distance dispersal of a subantarctic brooding bivalve (Gaimardia trapesina) by kelp rafting. Mar Biol 120:421-426

* Izhar R, Ben-Ami F (2015) Host age modulates parasite infectivity, virulence and reproduction. J Anim Ecol 84: 1018-1028

Jahnke R (1978) A study of gall diseased laminae of the marine brown alga Durvillaea potatorum (Labilladiere) Areschoug. BSc thesis, La Trobe University, Bundoora

Jones CG, Lawton JH, Shachak M (1997) Positive and negative effects of organisms as physical ecosystem engineers. Ecology 78:1946-1957

Kearse M, Moir R, Wilson A, Stones-Havas S and others (2012) Geneious Basic: an integrated and extendable desktop software platform for the organization and analysis of sequence data. Bioinformatics 28:1647-1649

Lawless JF (1987) Negative binomial and mixed Poisson regression. Can J Stat 15:209-225

* Li W, Zhang T, Tang X, Wang B (2010) Oomycetes and fungi: important parasites on marine algae. Acta Oceanol Sin 29:74-81

Locarnini RA, Mishonov AV, Antonov JI, Boyer TP and others (2013) Temperature. World Ocean Atlas 2013, Vol 1. NOAA Atlas NESDIS 73. US Dept of Comm, Silver Spring, MD

KLópez BA, Macaya EC, Tellier F, Tala F, Thiel M (2017a) The variable routes of rafting: stranding dynamics of floating bull-kelp Durvillaea antarctica (Fucales, Phaeophyceae) on beaches in the SE Pacific. J Phycol 53:70-84

López BA, Tellier F, Retamal-Alarcón JC, Pérez-Araneda K and others (2017b) Phylogeography of two intertidal seaweeds, Gelidium lingulatum and G. rex (Rhodophyta: Gelidiales), along the South East Pacific: patterns explained by rafting dispersal? Mar Biol 164:188

*Maier I, Parodi E, Westermeier R, Müller DG (2000) Maullinia ectocarpii gen. et sp. nov. (Plasmodiophorea), an intracellular parasite in Ectocarpus siliculosus (Ectocarpales, Phaeophyceae) and other filamentous brown algae. Protist 151:225-238

Millar AJ (2007) The Flindersian and Peronian Provinces. In: McCarthy PM, Orchard AE (eds) Algae of Australia: introduction. CSIRO Publishing, Clayton, p 554-559

Moore LB, Cribb AB (1952) The brown alga Durvillea antarctica in Australian waters. Nature 169:1100-1101

*Mouritsen KN, Tompkins DM, Poulin R (2005) Climate warming may cause a parasite-induced collapse in coastal amphipod populations. Oecologia 146:476-483

* Murúa P, Goecke F, Westermeier R, van West P, Küpper FC, Neuhauser S (2017) Maullinia braseltonii sp. nov. (Rhizaria, Phytomyxea, Phagomyxida): a cyst-forming parasite of the bullkelp Durvillaea spp. (Stramenopila, Phaeophyceae, Fucales). Protist 168:468-480

Neuhauser S, Kirchmair M, Gleason FH (2011) Ecological roles of the parasitic phytomyxids (plasmodiophorids) in marine ecosystems - a review. Mar Freshw Res 62: 365-371

* Neuhauser S, Kirchmair M, Bulman S, Bass D (2014) Crosskingdom host shifts of phytomyxid parasites. BMC Evol Biol 14:33

Nikula R, Fraser CI, Spencer HG, Waters JM (2010) Circumpolar dispersal by rafting in two subantarctic kelpdwelling crustaceans. Mar Ecol Prog Ser 405:221-230 
Nikula R, Spencer HG, Waters JM (2013) Passive rafting is a powerful driver of transoceanic gene flow. Biol Lett 9: 20120821

O'Hara TD, Poore GC (2000) Patterns of distribution for southern Australian marine echinoderms and decapods. J Biogeogr 27:1321-1335

Pawlowski J, Audic S, Adl S, Bass D and others (2012) CBOL protist working group: barcoding eukaryotic richness beyond the animal, plant, and fungal kingdoms. PLOS Biol 10:e1001419

Peters A, Breeman A (1993) Temperature tolerance and latitudinal range of brown algae from temperate Pacific South America. Mar Biol 115:143-150

Poulin R, Blanar CA, Thieltges DW, Marcogliese DJ (2012) Scaling up from epidemiology to biogeography: local infection patterns predict geographical distribution in fish parasites. J Biogeogr 39:1157-1166

R Development Core Team (2017) R: a language and environment for statistical computing. $\mathrm{R}$ Foundation for Statistical Computing, Vienna

Rohde K (2002) Ecology and biogeography of marine parasites. Adv Mar Biol 43:1-86

Ronquist F, Huelsenbeck JP (2003) MrBayes 3: Bayesian phylogenetic inference under mixed models. Bioinformatics 19:1572-1574

Rothäusler E, Gómez I, Hinojosa IA, Karsten U, Miranda L, Tala F, Thiel M (2011) Kelp rafts in the Humboldt Current: interplay of abiotic and biotic factors limit their floating persistence and dispersal potential. Limnol Oceanogr 56:1751-1763

Saavedra FG (2011) Associations between microbes and macroalgae: host, epiphyte and environmental effects. MSc thesis, Christian-Albrechts-Universität zu Kiel, Kiel

Santelices B, Castilla JC, Cancino J, Schmiede P (1980) Comparative ecology of Lessonia nigrescens and Durvillaea antarctica (Phaeophyta) in central Chile. Mar Biol 59:119-132

Schwelm A, Berney C, Dixelius C, Bass D, Neuhauser S (2016) The large subunit rDNA sequence of Plasmodio-

Editorial responsibility: Jean-Sébastien Lauzon-Guay, Dartmouth, Nova Scotia, Canada phora brassicae does not contain intra-species polymorphism. Protist 167:544-554

Silva N, Rojas N, Fedele A (2009) Water masses in the Humboldt Current System: properties, distribution, and the nitrate deficit as a chemical water mass tracer for Equatorial Subsurface Water off Chile. Deep Sea Res II 56: 1004-1020

Tala F, Velásquez M, Mansilla A, Macaya EC, Thiel M (2016) Latitudinal and seasonal effects on short-term acclimation of floating kelp species from the South-East Pacific. J Exp Mar Biol Ecol 483:31-41

* Tuya F, Cacabelos E, Duarte P, Jacinto D and others (2012) Patterns of landscape and assemblage structure along a latitudinal gradient in ocean climate. Mar Ecol Prog Ser 466:9-19

WWalsh PS, Metzger DA, Higuchi R (1991) Chelex 100 as a medium for simple extraction of DNA for PCR-based typing from forensic material. Biotechniques 10:506-513

Wang Y, Tian RM, Gao ZM, Bougouffa S, Qian PY (2014) Optimal eukaryotic 18S and universal 16S/18S ribosomal RNA primers and their application in a study of symbiosis. PLOS ONE 9:e90053

*Waters JM (2008) Marine biogeographical disjunction in temperate Australia: historical landbridge, contemporary currents, or both? Divers Distrib 14:692-700

*Waters JM, King TM, O'Loughlin PM, Spencer HG (2005) Phylogeographical disjunction in abundant high dispersal littoral gastropods. Mol Ecol 14:2789-2802

Waters JM, Fraser CI, Hewitt GM (2013) Founder takes all: density-dependent processes structure biodiversity. Trends Ecol Evol 28:78-85

*Weber XA, Edgar GJ, Banks SC, Waters JM, Fraser CI (2017) A morphological and phylogenetic investigation into divergence among sympatric Australian southern bull kelps (Durvillaea potatorum and D. amatheiae sp. nov.). Mol Phylogenet Evol 107:630-643

Wilson LJ, Weber XA, King TM, Fraser CI (2016) DNA extraction techniques for genomic analyses of macroalgae. In: Hu ZF, Fraser CI (eds) Seaweed phylogeography. Springer, Dordrecht, p 363-368

Submitted: May 29, 2017; Accepted: September 21, 2017 Proofs received from author(s): November 13, 2017 